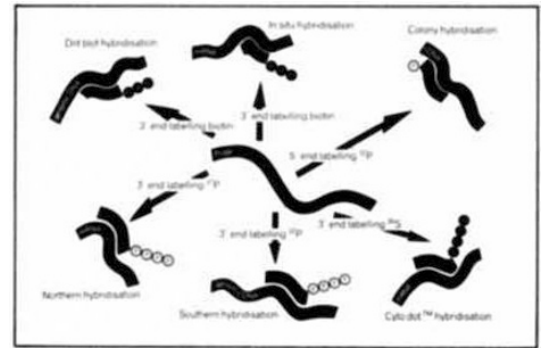

\section{PCR Controls}

British Biotechnology (Oxford, U.K.) has launched TAQCHECK, an amplification reaction control kit. It consists of four tubes containing amplification primers specific for particular fragment sizes that provide standard positive controls for amplification reactions. The target DNA is supplied at either $300,3,000,30,000$, or 300,000 copies per $100 \mu \mathrm{l}$ reaction.

Write in 806 on Reader Service Card

\section{cDNA Cloning}

The cDNA cloning system from Amersham International (Amersham, U.K.) uses the $\lambda$ gt 10 vector, which accepts DNA inserts of up to $7.6 \mathrm{~kb}$. Adaptors with a pre-formed EcoRI cohesive end are added to blunt-ended cDNA, avoiding the need to methylate the cDNA and to treat the preparation with EcoRI in order to generate cohesive ends. Purified adapted DNA can be inserted into the vector arms and introduced into host $E$. coli after in-vitro packaging.

$$
\text { Write in } 804 \text { on Reader Service Card }
$$

\section{Progressive Deletions}

The Erase-a-Base ${ }^{T M}$ system from Promega (Madison, WI) helps in constructing plasmid or M13 subclones containing progressive deletions of any inserted DNA. Exonuclease III is used to digest DNA from a $5^{\prime}$ protruding or blunt end. By removing aliquots at various times, users can make a set of unidirectional deletions spanning several $\mathrm{kbp}$. The kit includes exonuclease III, S1 nuclease, Klenow DNA polymerase, ligase, and a range of standard buffers, nucleotide triphosphates, and other reagents.

Write in 803 on Reader Service Card

\section{DNA Miniprep}

Miniprep Kit Plus from Pharmacia LKB Biotechnology (Uppsala, Sweden) provides all reagents necessary for making routine minipreps. In addition, the kit's columns enable the preparation of DNA for sequencing, 5 '-end labeling, transcribing, or preparing nested deletions. The kit contains reagents for 500 minipreps and 12 pre-packed Sephacryl S-400 columns, which remove protein and RNA and avoid the need for phenol extraction.

Write in 807 on Reader Service Card

\section{Capillary Separation Kit}

Applied Biosystems (Foster City, CA) introduces the SepraGene ${ }^{T M}$ kit for analysis of double-stranded DNA by capillary electrophoresis. Supplied with separation reagents, molecular weight standards, pre-assembled capillaries, and protocols, the kits determine the size and concentration of unknown fragments in $<15$ min., using no more than $10 \mathrm{nl}$ of sample. SepraGene 500 is designed for the $100-1,000$ bp range; SepraGene 5000 is for the 1,000-7,000 bp range.

Write in 802 on Reader Service Card

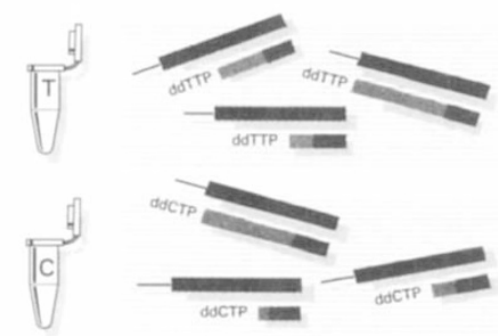

\section{Efficient Cloning}

By altering the vector in its Lambda Zap $^{\circledR}$ II system, Stratagene (La Jolla, CA) has enhanced the color distinction made between recombinant and non-recombinant clones. The original Lambda Zap vector contained the Sam 100 mutation, which meant that it could only be grown on $E$. coli host strains with a SupF genotype. The new vector no longer contains the mutation and can be grown instead on the E. coli strain XL1-Blue, which confers enhanced blue color upon non-recombinant clones.

Write in 805 on Reader Service Card

\section{Mapping Probe Kit}

For rapid mapping of human genomic DNA cloned into yeast artificial chromosomes (YACs), bacteriophages, cosmids, and other vectors, Lagan (Detroit, MI) offers a series of repetitive-frequency sequence probes. Kits contain six sequence probes 102-526 bases long, the targets for which occur between 300 and 6,700 in the human haploid genome.
Standard selections of probes or custom kits are available.

Write in 810 on Reader Service Card

\section{PCRime Busting}

The first commercial DNA profiling product to use PCR technology has been launched by Cetus (Emeryville, CA). The AmpliType ${ }^{\mathrm{TM}}$ DNA amplification and typing kit brings the dot-blot format, familiar to molecular biologists, into the forensic laboratory. The kit is based on typing the HLA DQ $\alpha$ locus-but genetically rather than immunologically. Cetus believes that adding PCR to this method makes it cost-effective enough to use as a screening tool.

Write in 811 on Reader Service Card

\section{In-Vitro Mutagenesis}

The T7-GEN ${ }^{\text {TM }}$ kit from United States Biochemical (Cleveland, $\mathrm{OH}$ ) contains sufficient reagents for $20 \mathrm{in}$ vitro mutagenesis reactions. Once a mutant primer is annealed to singlestranded wild-type DNA, T7 DNA polymerase completes the mutant strand synthesis in the presence of 5 methyl-dC. The wild-type strand is then removed by nicking with the restriction enzyme $M s p$ I followed by exonuclease III digestion. The kit provides the non-restricting SDM strain of $E$. coli for recovery of mutant DNA.

Write in 808 on Reader Service Card

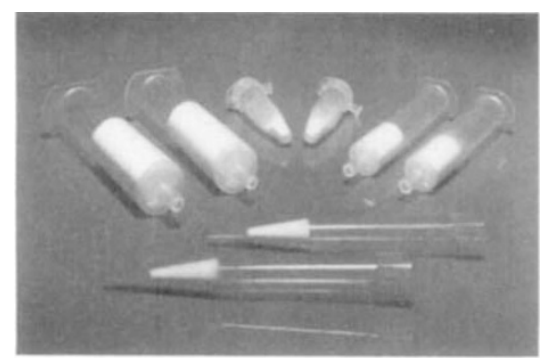

DNA Purification

Nucleobond AX cartridges from The Nest Group (Southborough, MA) provide anion exchange isolation of plasmid DNA, phage lambda DNA, genomic DNA (up to $200 \mathrm{~kb}$ ), single-stranded DNA, mRNA, and large nucleic acids. Compatible with syringes and pipettes with Luer ${ }^{\circledR}$ connectors, the disposable cartridges do not require $\mathrm{CsCl}$ reagents or the use of HPLC or ultracentrifuge equipment. Capacities range from $10 \mathrm{ng}$ to $1 \mathrm{mg}$ with recoveries from 85100 percent.

Write in 801 on Reader Service Card 